\title{
Syntheses of Ruthenium(II)-Poly(4-vinylpyridine) Complexes and Their Spectroscopic Studies
}

\author{
Takeo SHIMIDZU, * Kansei IZAKI, \\ Yasuo AKAI, and Tomokazu IYODA \\ Department of Hydrocarbon Chemistry, Faculty of Engineering, \\ Kyoto University, Kyoto 606, Japan.
}

(Received January 22, 1981)

\begin{abstract}
The $\mathrm{Ru}(\mathrm{II})$-poly(4-vinylpyridine) complexes, $\left[\mathrm{Ru}(\mathrm{bpy})_{2}(\mathrm{PVP})_{2}\right] \mathrm{Cl}_{2}$, and $\left[\mathrm{Ru}(\mathrm{bpy})_{2}(\mathrm{PVP})(\mathrm{py})\right] \mathrm{Cl}_{2}$ have been synthesized and compared spectroscopically with the monomeric $\left[\mathrm{Ru}(\mathrm{bpy})_{2}(\mathrm{py})_{2}\right] \mathrm{Cl}_{2}$ complex, where py is pyridine, bpy is $2,2^{\prime}$-bipyridine, and PVP is poly(4vinylpyridine). The polymeric $\mathrm{Ru}(\mathrm{II})$ complexes were synthesized by the substitution of $\mathrm{Cl}$ in $\mathrm{Ru}(\mathrm{bpy})_{2} \mathrm{Cl}_{2}$ for poly(4-vinylpyridine) in methanol. The six-coordinated polymeric $\mathrm{Ru}$ (II) complex, $\left[\mathrm{Ru}(\mathrm{bpy})_{2}(\mathrm{PVP})_{2}\right] \mathrm{Cl}_{2}$, was insoluble in water due to an intermolecular ligand complex formation, while one substituted complex, $\left[\mathrm{Ru}(\mathrm{bpy})_{2}(\mathrm{PVP})(\mathrm{py})\right] \mathrm{Cl}_{2}$, was soluble in water. The absorption maximum of $\left[\mathrm{Ru}(\mathrm{bpy})_{2}(\mathrm{PVP})(\mathrm{py})\right] \mathrm{Cl}_{2}$ was red-shifted ca. $10 \mathrm{~nm}$ from that of $\left[\mathrm{Ru}(\mathrm{bpy})_{2}(\mathrm{py})_{2}\right] \mathrm{Cl}_{2}$. Also, the red-shift was observed in the emission spectrum. The emission intensity of the polymeric $\mathrm{Ru}$ (II) complex was smaller than that of the monomeric one, whereas the emission lifetime was a little different. The difference in energy transfer processes for the above complexes is discussed.

KEY WORDS Ru(II)-Poly(4-vinylpyridine) Complex / Polymeric Ru(II)

Complex / Intermolecular Ligand Complex / Energy Transfer Processes /
\end{abstract}

Complexation reactions accompanied by the strain of a polymer chain give different profiles from those of low molecular weight ligands, and it has been shown that the composition and the stabilization of polymer complexes differ widely from those of monomeric analogue. ${ }^{1-5}$ Further, the effects of a polymer on the reaction field of a large variety of reactions are well documented in the literature. ${ }^{6,7}$ The specific environment given by the polymer, for example, influences the nucleophilicity of the nucleophile. ${ }^{8,9}$ Moreover, the high catalytic activity of the polymer complex has also been shown: poly(acrylhydroxamic acid)-Cu(II) as the catalyst of the decomposition of hydrogen peroxide, ${ }^{10}$ polymeric phosphine-Pd(II) complex as the catalyst of hydrogenation of methyl ester of unsaturated fatty acid, ${ }^{11}$ and polymeric metalloporphyrins as the reversible oxygen carrier. ${ }^{12-14}$

Also, the photochemical redox properties of $\left[\mathrm{Ru}(\mathrm{bpy})_{3}\right]^{2+}$ derivatives dispersed in monolayers which decomposed water photochemically into hydrogen and oxygen have been shown. ${ }^{15}$ The photochemical properties of $\left[\mathrm{Ru}(\mathrm{bpy})_{3}\right]^{2+}$ using flash photolysis and pulse radiolysis have been investigated, ${ }^{16}$ and the effects of polyelectrolyte and micelle on its photochemical process have also been studied recently. ${ }^{17,19}$ Maisel and coworkers have shown the utilization of the $\left[\mathrm{Ru}(\mathrm{bpy})_{3}\right]^{2+}-\mathrm{Cu}^{2+}$ system in solar energy conversion in the presence of polyelectrolyte. ${ }^{17}$

It is thus expected that the $\mathrm{Ru}(\mathrm{II})$ complex containing a polymeric ligand will show a specific properties. Recently, the findings of both Clear et $a l$. and Kaneko et al. have been published. ${ }^{18}$ In view of the considerable interest in polymeric ligands which give a specific environment to the ligand field, polymeric $\mathrm{Ru}(\mathrm{II})$ complexes, $\left[\mathrm{Ru}(\mathrm{bpy})_{2}(\mathrm{PVP})_{2}\right] \mathrm{Cl}_{2}$, and $\left[\mathrm{Ru}(\mathrm{bpy})_{2}\right.$ (PVP) (py)]Cl were synthesized and their spectroscopic properties in regard to the analogue, $\left[\mathrm{Ru}(\mathrm{bpy})_{2}(\mathrm{py})\right] \mathrm{Cl}_{2}$ were investigated.

\section{RESULTS AND DISCUSSION}

Complexation of $\mathrm{Ru}(\text { bpy })_{2} \mathrm{Cl}_{2}$ with Poly(4-vinylpyridine)

Polymeric $\mathrm{Ru}(\mathrm{II})$ complexes, $\left[\mathrm{Ru}(\mathrm{bpy})_{2}(\mathrm{PVP})_{2}\right]$ 


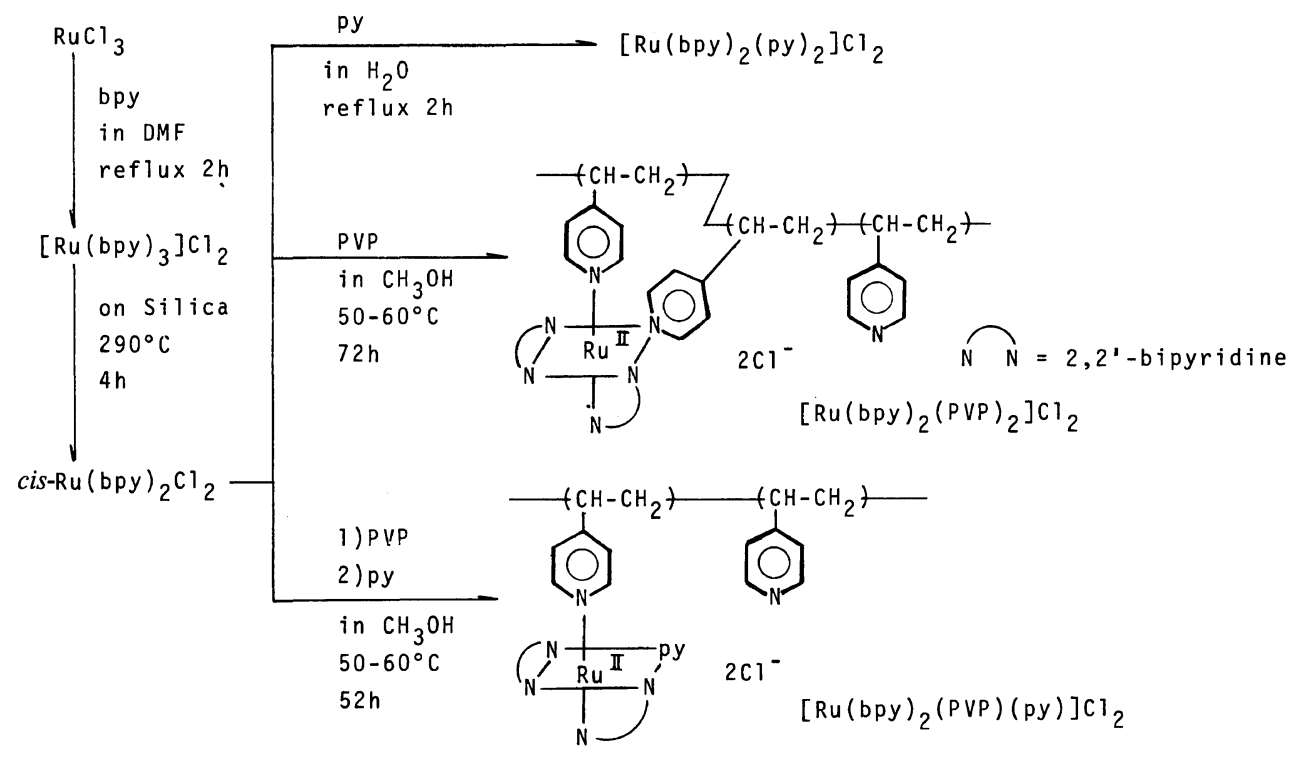

Scheme 1.

$\mathrm{Cl}_{2}$, and $\left[\mathrm{Ru}(\mathrm{bpy})_{2}(\mathrm{PVP})(\mathrm{py})\right] \mathrm{Cl}_{2}$ were synthesized by the route shown in Scheme 1 . $\mathrm{Ru}(\mathrm{bpy})_{2} \mathrm{Cl}_{2}$ has been well studied by Dewer and co-workers. ${ }^{20,21}$ $\mathrm{Ru}(\mathrm{bpy})_{2} \mathrm{Cl}_{2}$ derived from $\left[\mathrm{Ru}(\mathrm{bpy})_{3}\right] \mathrm{Cl}_{2}$ has the cis-form. This complex is labile and $\mathrm{Cl}$ can be easily substituted by many other ligands. Accordingly, this complex was used as the starting material for the synthesis of polymeric $\mathrm{Ru}(\mathrm{II})$ complexes. All the monomeric Ru(II) complexes, $[\mathrm{Ru}-$ (bpy) $\left.)_{3}\right] \mathrm{Cl}_{2}, \mathrm{Ru}(\mathrm{bpy})_{2} \mathrm{Cl}_{2}$, and $\left[\mathrm{Ru}(\mathrm{bpy})_{2}(\mathrm{py})_{2}\right] \mathrm{Cl}_{2}$ were prepared according to the literature..$^{21-23} \mathrm{It}$ is well-known that poly(4-vinylpyridine) provides a good coordination binding site for various metals.

When $\mathrm{Ru}(\mathrm{bpy})_{2} \mathrm{Cl}_{2}$ was added to a methanol solution of poly(4-vinylpyridine), a color change from violet to deep yellow was observed. The spectral changes in this reaction in the visible region are shown in Figure 1. $\mathrm{Ru}(\mathrm{bpy})_{2} \mathrm{Cl}_{2}$ in methanol had two peaks at 508 and $356 \mathrm{~nm}$. Absorbance changes in two stages followed by the reaction were observed. The first stage was a decrease in absorbance at $508 \mathrm{~nm}$, an increase at $496 \mathrm{~nm}$, and an increase at $350 \mathrm{~nm}$ with a slight blue shift. The second stage followed the first stage. Absorbances at $470 \mathrm{~nm}$ and $346 \mathrm{~nm}$ increased, while absorbance at $496 \mathrm{~nm}$ decreased. The profile of the change in this absorption spectrum was similar to that of the reaction of $\mathrm{Ru}(\mathrm{bpy})_{2} \mathrm{Cl}_{2}$ and pyridine under the

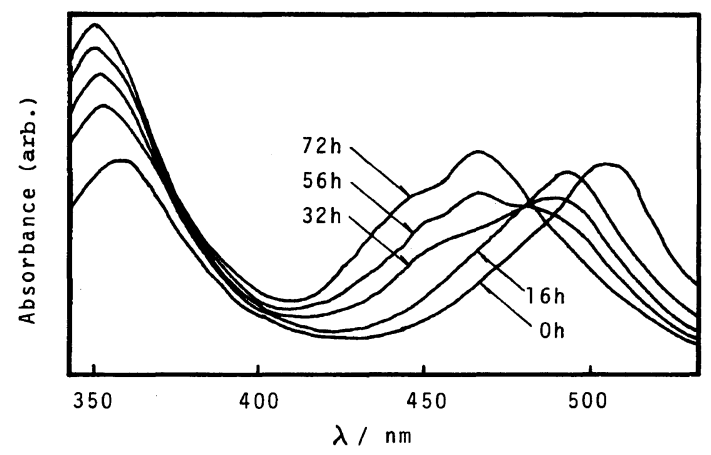

Figure 1. Electric absorption spectral changes of $\mathrm{Ru}(\mathrm{bpy})_{2} \mathrm{Cl}_{2}$ with poly(4-vinylpyridine) in methanol at $50-60^{\circ} \mathrm{C}$.

same conditions. Accordingly, the following consecutive reactions were considered.

$$
\mathrm{Ru}(\mathrm{bpy})_{2} \mathrm{Cl}_{2}+\mathrm{PVP} \longrightarrow\left[\mathrm{Ru}(\mathrm{bpy})_{2}(\mathrm{PVP}) \mathrm{Cl}\right] \mathrm{Cl}
$$

$$
\begin{aligned}
{\left[\mathrm{Ru}(\mathrm{bpy})_{2}(\mathrm{PVP}) \mathrm{Cl}\right] \mathrm{Cl}+} & \mathrm{PVP} \longrightarrow \\
{\left[\mathrm{Ru}(\mathrm{bpy})_{2}(\mathrm{PVP})_{2}\right] \mathrm{Cl}_{2} } &
\end{aligned}
$$

In the second substitution, where pyridine was used in lieu of PVP, a faster spectral change than that in the substitution with PVP was observed. Also, the solution treated with pyridine instead of PVP in the second substitution has 473 and $350 \mathrm{~nm}$ absorbances, both longer than those of $\left[\mathrm{Ru}(\mathrm{bpy})_{2}(\mathrm{py})_{2}\right] \mathrm{Cl}_{2}$. Still, 
it was considered that the resulted solution might contain $\left[\mathrm{Ru}(\mathrm{bpy})_{2}(\mathrm{PVP})_{2}\right] \mathrm{Cl}_{2}$ and $\left[\mathrm{Ru}(\mathrm{bpy})_{2}(\mathrm{py})_{2}\right]$ $\mathrm{Cl}_{2}$ besides $\left[\mathrm{Ru}(\mathrm{bpy})_{2}(\mathrm{PVP})(\mathrm{py})\right] \mathrm{Cl}_{2}$. However, $\left[\mathrm{Ru}(\mathrm{bpy})_{2}(\mathrm{PVP})_{2}\right] \mathrm{Cl}_{2}$ did not form by this procedure, since the addition of water gave no precipitate. The low molecular weight complex, $\left[\mathrm{Ru}(\mathrm{bpy})_{2}(\mathrm{py})_{2}\right] \mathrm{Cl}_{2}$ and the starting materials were removed by dialysis.

These results can explain why the pyridine moiety in the polymer binded to the $\mathrm{Ru}$ (II) complex by a substitution reaction in the first stage (reaction (1)), and why pyridine then coordinated with $\left[\mathrm{Ru}(\mathrm{bpy})_{2}(\mathrm{PVP}) \mathrm{Cl}\right] \mathrm{Cl}$ in lieu of another pyridine moiety in PVP. The precipitate from the concentrated dialyzed solution with dimethyl ether was the polymeric $\mathrm{Ru}(\mathrm{II})$ complex, $\left[\mathrm{Ru}(\mathrm{bpy})_{2}(\mathrm{PVP})(\mathrm{py})\right] \mathrm{Cl}_{2}$.

An aqueous solution of this complex was stable in water for 3 days; after this, the spectral changes due to ligand substitution with the solvent were observed even when stored in dark.

\section{The Absorption Properties of Polymeric Ru(II) Complex}

According to the literature, ${ }^{24}$ the visible absorption $\left(\varepsilon_{452}=1.4 \times 10^{4} \mathrm{M}^{-1} \mathrm{~cm}^{-1}\right)$ of $\left[\mathrm{Ru}(\mathrm{bpy})_{3}\right]^{2+}$ is assigned to the spin-allowed charge transfer from the metal $d$ orbitals to the $\pi^{*}$ orbitals of the ligand, and the absorbance at $290 \mathrm{~nm}$ in the UV region is assigned to the $\pi-\pi^{*}$ transition of 2,2'-bipyridine.

The $\lambda_{\max }$ of the absorption spectra of polymeric and related complexes are shown in Table I. Both polymeric $\mathrm{Ru}(\mathrm{II})$ and monomeric complexes have two intense absorptions in the visible region. These two intense bands are designated as the charge transfer transitions from the $\mathrm{Ru}(\mathrm{II}) \mathrm{d}$ orbitals to the $\pi^{*}$ orbitals of $2,2^{\prime}$-bipyridine. ${ }^{25-27}$

The absorption spectrum of the pyridine moiety in the polymeric $\mathrm{Ru}(\mathrm{II})$ complex, $\left[\mathrm{Ru}(\mathrm{bpy})_{2}(\mathrm{PVP})-\right.$ (py) $] \mathrm{Cl}_{2}$, in the UV region was similar to that in free poly(4-vinylpyridine). Assuming that the absorbance of poly(4-vinylpyridine) in the polymer complex is $\varepsilon_{256}=1740 \mathrm{M}^{-1} \mathrm{~cm}^{-1}$, it was estimated that about $10 \%$ of the pyridine moiety coordinated with $\mathrm{Ru}(\mathrm{bpy})_{2} \mathrm{Cl}_{2}$.

Table I shows the significant differences of the polymeric $\mathrm{Ru}(\mathrm{II})$ complex from the monomeric analogue. The characteristics of the polymeric complex are (a) the red shift of $\lambda_{\max }$ in the visible and UV region, (b) the increase of the half-width. The molecular orbital diagram ${ }^{28}$ of $\left[\mathrm{Ru}(\mathrm{bpy})_{3}\right]^{2+}$ in-
Table I. Absorption spectral data for $\mathrm{Ru}(\mathrm{II})$ complexes $^{\mathrm{a}}$

\begin{tabular}{lccc}
\hline \multirow{1}{*}{ Complexes } & \multicolumn{3}{c}{$\lambda_{\max } / \mathrm{nm}$} \\
\cline { 2 - 4 } & $\pi-\pi^{*}$ & \multicolumn{2}{c}{$d-\pi^{*}$} \\
\hline $\mathrm{Ru}(\mathrm{bpy})_{2} \mathrm{Cl}_{2}$ & & 356 & 508 \\
{$\left[\mathrm{Ru}(\mathrm{bpy})_{2}(\mathrm{py}) \mathrm{Cl}\right] \mathrm{Cl}$} & & 352 & 496 \\
{$\left[\mathrm{Ru}(\mathrm{bpy})_{2}(\mathrm{py})_{2}\right] \mathrm{Cl} l_{2}$} & 290 & 338 & 461 \\
{$\left[\mathrm{Ru}(\mathrm{bpy})_{2}(\mathrm{PVP}) \mathrm{Cl}\right] \mathrm{Cl}$} & & 350 & 500 \\
{$\left[\mathrm{Ru}(\mathrm{bpy})_{2}(\mathrm{PVP})(\mathrm{py})\right] \mathrm{Cl}_{2}$} & 295 & 350 & 473 \\
{$\left[\mathrm{Ru}(\mathrm{bpy})_{2}(\mathrm{PVP})_{2}\right] \mathrm{Cl}_{2}$} & & 346 & 470 \\
\hline
\end{tabular}

a In methanol, at room temperature.

dicated that the pyridine functions as a $\pi$ acceptor ligand, so that the interaction between the metal $d$ orbital and ligand includes a $\pi$ back donation; that is, such a chelate ligand has a resonance effect like $2,2^{\prime}$-bipyridine. ${ }^{29}$ Therefore, the red-shift of the $\pi-$ $\pi^{*}$ transitions of 2,2'-bipyridine can be considered as a result of a resonance stability smaller than the monomeric analogue. Also, in regard to the redshift in the visible region, it may be considered that the energy gap between the ground state and the excited $d-\pi^{*}$ level becomes smaller than that of the monomeric analogue owing to a decrease in the resonance effect. Certain factors for these phenomena can be considered: the steric effect of the polymeric ligand having a methylene chain in the backbone and other pyridine moiety in adjacent to the complex, ${ }^{4,5}$ the change in the donability of the polymeric pyridine moiety compared with monomeric pyridine, ${ }^{8,9}$ and the change in the microenvironment around the complex, such as the polarity of the solvent. ${ }^{5}$ At the present, it is not clear as to what is mainly responsible factor for the above phenomena. The above discussion leads to the conclusion that polymeric $\mathrm{Ru}(\mathrm{II})$ complexes are rather labile in comparison with the monomeric analogue. The following experimental results also support this conclusion: The solution stabilities of the polymeric $\mathrm{Ru}(\mathrm{II})$ and monomeric complex, in dark, were maintained for 3 days and 7 days, respectively. After this, substitution of the ligand with the solvent gradually took place. Also, the increase in the half-width of the absorbance suggests the existence of an interaction between the polymeric $\mathrm{Ru}(\mathrm{II})$ complex, and solvent molecules or the free pyridine moiety in the 
Table II. Emission spectral data for Ru(II) Complexes

\begin{tabular}{cccc}
\hline \multicolumn{1}{c}{ Complexes } & Excitation $/ \mathrm{nm}$ & $\lambda_{\max } / \mathrm{nm}^{\mathrm{a}}$ & Lifetime $/ \mu \mathrm{s}^{\mathrm{b}}$ \\
\hline$\left[\mathrm{Ru}(\mathrm{bpy})_{2}(\mathrm{py})_{2} \mathrm{Cl}_{2}\right.$ & 460 & 580 & $0.06 \pm 0.02$ \\
{$\left[\mathrm{Ru}(\mathrm{bpy})_{2}(\mathrm{PVP})(\mathrm{py})\right] \mathrm{Cl}_{2}$} & 470 & 591 & $0.54 \pm 0.04$ \\
{$\left[\mathrm{Ru}(\mathrm{bpy})_{3}\right] \mathrm{Cl}_{2}$} & $454^{\mathrm{c}}$ & $620^{\mathrm{c}}$ & $0.65^{\mathrm{c}}$ \\
\hline
\end{tabular}

${ }^{a}$ In methanol, at $77 \mathrm{~K}$.

b In $\mathrm{H}_{2} \mathrm{O}$, at room temperature.

c References 27 and 28.

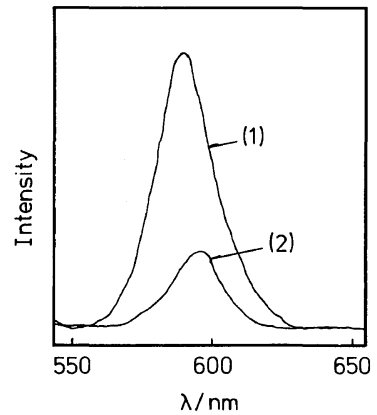

Figure 2. Luminescence spectra of $\mathrm{Ru}(\mathrm{II})$ complexes in water at room temperature: (1) $\left[\mathrm{Ru}(\mathrm{bpy})_{2}(\mathrm{py})_{2}\right] \mathrm{Cl}_{2}$; (2) $\left[\mathrm{Ru}(\mathrm{bpy})_{2}(\mathrm{PVP})(\mathrm{py})\right] \mathrm{Cl}_{2}$. Concentrations of $\mathrm{Ru}(\mathrm{II})$ complexes are $1.3 \times 10^{-5} \mathrm{~mol} \mathrm{dm}^{-3}, 1.8 \times 10^{-5} \mathrm{~mol} \mathrm{dm}^{-3}$, respectively.

polymer.

The difference in the absorption for $\left[\mathrm{Ru}(\mathrm{bpy})_{2}\right.$ $\left.(\mathrm{PVP})_{2}\right]^{2+}$ and $\left[\mathrm{Ru}(\mathrm{bpy})_{2}(\mathrm{PVP})(\mathrm{py})\right]^{2+}$ in methanol has also been observed in the visible region. The former had $\lambda_{\max }=470$ and $346 \mathrm{~nm}$ which blue-shifted by several nm's compared with the latter. This blue shift suggests that a sort of chelate effect took place in the complexation of $\left[\mathrm{Ru}(\mathrm{bpy})_{2}(\mathrm{PVP})_{2}\right]^{2+}$; that is, the pyridine moiety adjacent to the coordinated pyridine moiety in the complex became attached $\left[\mathrm{Ru}(\mathrm{bpy})_{2}(\mathrm{PVP}) \mathrm{Cl}\right]^{+}$ to form a stable complex, $\left[\mathrm{Ru}(\mathrm{bpy})_{2}(\mathrm{PVP})_{2}\right]^{2+}$, rather than $\left[\mathrm{Ru}(\mathrm{bpy})_{2}(\mathrm{PVP})(\mathrm{py})\right]^{2+}$.

Emission Properties of the Polymer Ru(II) Complex

The emission of $\left[R u(b p y)_{3}\right]^{2+}$ was characterized by the authors. ${ }^{24,30-35}$ This emission was determined to be a phosphorescence from the ${ }^{3}\left(d-\pi^{*}\right)$ to the ground state, with a natural lifetime of 0.65 $\mu$ sec. Recently, Crosby and co-workers showed that this emission arises from three closely spaced electronic states with symmetries $A_{1}, E_{1}$, and $A_{2}$ in order of increasing energy. ${ }^{36,37}$ These states are in rapid equilibrium and the emission properties of the excited states are primarily determined by the properties of the $A_{2}$ state except at very low temperatures. The emission spectra of $\left[\mathrm{Ru}(\mathrm{bpy})_{2}(\mathrm{PVP})(\mathrm{py})\right]^{2+}$ and $\left[\mathrm{Ru}(\mathrm{bpy})_{2}(\mathrm{py})_{2}\right]^{2+}$ at room temperature are shown in Figure 3. The $\lambda_{\max }$ of the complex at $77 \mathrm{~K}$ are listed in Table II. The emission lifetime of the complexes in water at room temperature are also listed. The excitation spectrum of $\left[\mathrm{Ru}(\mathrm{bpy})_{2}(\mathrm{py})_{2}\right]^{2+}$ showed a strong band at $460 \mathrm{~nm}$, while the absorption spectrum showed 350 and $460 \mathrm{~nm}$, as indicated by Figure 2. This implies that the absorption at $350 \mathrm{~nm}$ arises from the contribution to the emission. As seen in Table II, the emissions of $\left[\mathrm{Ru}(\mathrm{bpy})_{2} \mathrm{X}_{2}\right]^{2+}$ at $c a .590 \mathrm{~nm}$ are considered to result from the radiation process from the ${ }^{3}\left(d-\pi^{*}\right)$ states of $\mathrm{Ru}(\mathrm{II})-2,2^{\prime}$-bipyridine. The expected emission from the $d-\pi^{*}$ state of $\mathrm{Ru}(\mathrm{II})$ pyridine might take place at $400 \mathrm{~nm}$, although it could not be observed directly owing to light scattering in the solution. That the emission lifetime of the polymeric and monomeric $\mathrm{Ru}(\mathrm{II})$ complexes shown in Table II were almost same as that of $\left[\mathrm{Ru}(\mathrm{bpy})_{3}\right]^{2+}$ was ascertained from the above assignment.

The maximum of the emission of polymeric $\mathrm{Ru}(\mathrm{II})$ complex was red-shifted in $c a .10 \mathrm{~nm}$ compared with the monomeric complex. The difference in the coordination between the polymeric and monomeric one to the metal was responsible for this shift. This shift in ligand emission maximum also implies a ${ }^{3}\left(d-\pi^{*}\right)-{ }^{1} A_{1}$ transition. ${ }^{35}$ Also, the halfwidth of the emission of polymeric $\mathrm{Ru}(\mathrm{II})$ complex, $\left[\mathrm{Ru}(\mathrm{bpy})_{2}(\mathrm{PVP})(\mathrm{py})\right]^{2+}$, decreased. This is interesting in regard to the CTTS (charge transfer to solvent) nature of the complex. According to a recent report, ${ }^{19}$ the emission spectrum of $\left[\mathrm{Ru}(\mathrm{bpy})_{3}\right]^{2+}$ in the micelles was affected by the 
property of carbon chain portion. Also, the emission spectra of $\left[\mathrm{Ru}(\mathrm{bpy})_{3}\right]^{2+}$ in several alcohols were red-shifted with increasingly longer hydrocarbon chains and the half-widths of the spectra were $15 \mathrm{~nm}$ smaller than in water. Therefore, it is suggested that the decrease in the half-width of the emission spectrum was due to the interaction between the complex and the polymer chain, or the specific interaction between the complex and the solvent.

The other characteristics of the polymer $\mathrm{Ru}(\mathrm{II})$ complex, $\left[\mathrm{Ru}(\mathrm{bpy})_{2}(\mathrm{PVP})(\mathrm{py})\right] \mathrm{Cl}_{2}$, is that the intensity of the emission spectrum was one-fourth that of the monomeric Ru(II) complex.

Assuming that the intersystem crossing from $S_{1}$ to $T_{1}$ of $\mathrm{Ru}(\mathrm{II})$ complex is very fast, ${ }^{24}$ the natural lifetime of polymeric $\mathrm{Ru}(\mathrm{II})$ complex $\left(\tau_{\text {poly }}\right)$ and the monomeric analogue $\left(\tau_{\text {mono }}\right)$ are represented as,

$$
\begin{aligned}
\tau_{\text {poly }} & =1 /\left(k_{\mathrm{p}}+k_{\mathrm{c}}+k_{\mathrm{sol}}+\Sigma k\right) \\
\tau_{\text {mono }} & =1 /\left(k_{\mathrm{p}}{ }^{\prime}+k_{\mathrm{c}}{ }^{\prime}+k_{\mathrm{sol}}{ }^{\prime}+\Sigma k^{\prime}\right)
\end{aligned}
$$

where $k_{\mathrm{p}}\left(k_{\mathrm{p}}{ }^{\prime}\right), k_{\mathrm{c}}\left(k_{\mathrm{c}}{ }^{\prime}\right), k_{\mathrm{sol}}\left(k_{\mathrm{sol}}^{\prime}\right)$, and $\sum k\left(\Sigma k^{\prime}\right)$ show the rate constants of phosphorescence, internal conversion, electron transfer or energy transfer to solvent, and the other processes, respectively. $I_{\text {poly }}$ and $I_{\text {mono }}$ which are the quantum yields of the phosphorescence of polymeric and monomeric complex are related to the lifetimes as,

$$
\begin{gathered}
I_{\text {poly }}=k_{\mathrm{p}} \cdot \tau_{\text {poly }} \\
I_{\text {mono }}=k_{\mathrm{p}}{ }^{\prime} \cdot \tau_{\text {mono }}
\end{gathered}
$$

Equations 5 and 6 can be combined to give eq 7 ,

$$
\frac{I_{\text {mono }}}{I_{\text {poly }}}=\frac{k_{\mathrm{p}}{ }^{\prime} \cdot \tau_{\text {mono }}}{k_{\mathrm{p}} \cdot \tau_{\text {poly }}}
$$

Figure 3 shows that $I_{\text {mono }} / I_{\text {poly }}$ was $c a$. 4 . From the lifetime of each complex tabulated in Table II, $\tau_{\text {mono }} / \tau_{\text {poly }}$ was $c a .1$. Therefore, from eq 7 ,

$$
k_{\mathrm{p}}^{\prime} / k_{\mathrm{p}}=4
$$

and from eq 3 and 4 ,

$$
\left(k_{\mathrm{p}}+k_{\mathrm{c}}+k_{\mathrm{sol}}+\Sigma k\right) \simeq\left(k_{\mathrm{p}}{ }^{\prime}+k_{\mathrm{c}}{ }^{\prime}+k_{\mathrm{sol}}{ }^{\prime}+\Sigma k^{\prime}\right)
$$

was obtained. Accordingly, eq 8 and 9 give eq 10 ,

$$
\left(k_{\mathrm{c}}+k_{\mathrm{sol}}+\Sigma k\right)-\left(k_{\mathrm{c}}{ }^{\prime}+k_{\mathrm{sol}}^{\prime}+\Sigma k^{\prime}\right)=3 k_{\mathrm{p}}>0
$$

This equation explicitly suggests that the interaction between the polymeric complex and the solvent or the polymer chain is larger than that for the monomeric complex.

\section{EXPERIMENTAL}

\section{Materials}

Tris(2,2'-bipyridine) ruthenium(II) dichloride, $\left[\mathrm{Ru}(\mathrm{bpy})_{3}\right] \mathrm{Cl}_{2}$, was prepared by Meyer's method, ${ }^{22}$ and was characterized by its UV-visible spectrum in water. Bis $\left(2,2^{\prime}\right.$-bipyridine) ruthenium(II) dichloride, $\mathrm{Ru}(\mathrm{bpy})_{2} \mathrm{Cl}_{2}$, as the starting material for polymeric $\mathrm{Ru}(\mathrm{II})$ complexes was prepared by the pyrolysis of $\left[\mathrm{Ru}(\mathrm{bpy})_{2}\right] \mathrm{Cl}_{2}$ according to the procedure indicated by Liu et al., ${ }^{23}$ and was characterized by the electronic spectrum. ${ }^{22}$

Poly(4-vinylpyridine) was prepared by the radical polymerization of 4-vinylpyridine in a sealed glass tube, with 2,2'-azobisisobutyronitrile as the initiator. The polymer was dissolved in chloroform, and precipitated with dimethylether at room temperature. The polymer was purified by reprecipitation before use. The degree of polymerization was estimated to be $c a .1 .1 \times 10^{4}$.

\section{Preparation}

$\left[R u(b p y)_{2}(P V P)_{2}\right] C l_{2} \cdot \mathrm{Ru}(\mathrm{bpy})_{2} \mathrm{Cl}_{2}\left(1.2 \times 10^{-6}\right.$ mol) was added to $100 \mathrm{ml}$ of methanol solution of poly(4-vinylpyridine) $\left(1.2 \times 10^{-5} \mathrm{~mol}\right)$. The reaction was carried out at $50-60^{\circ} \mathrm{C}$ until no further change could be detected in the UV-visible spectroscopy. The reaction was completed in $72 \mathrm{~h}$. The solution was then condensed to $c a .20 \mathrm{ml}$ and water was added. A deep red precipitate, $\left[\mathrm{Ru}(\mathrm{bpy})_{2}(\mathrm{PVP})_{2}\right] \mathrm{Cl}_{2}$, was collected and dried in vacuo.

$\left[R u(b p y)_{2}(P V P)(p y)\right] C l_{2} \cdot \mathrm{Ru}(\mathrm{bpy})_{2} \mathrm{Cl}_{2}$ was added to $100 \mathrm{ml}$ of a methanol solution of poly(4vinylpyridine), and heated to $50-60^{\circ} \mathrm{C}$. When the absorbance at $496 \mathrm{~nm}$ become optimum (see Figure 1) after $16 \mathrm{~h}, 5 \mathrm{ml}$ of pyridine was added to the solution, and heating was continued until no further spectral changes could be detected. The total reaction was completed in $52 \mathrm{~h}$. After cooling to room temperature, all of the solution was condensed to $c a .10 \mathrm{ml}$ under reduced pressure and then filtered. The filtrate was purified by dialysis in water for 1 day to remove any starting material, pyridine and $\left[\mathrm{Ru}(\mathrm{bpy})_{2}(\mathrm{py})_{2}\right] \mathrm{Cl}_{2}$. The dialyzed solution was concentrated and poured into dimethylether to yield the polymeric $\mathrm{Ru}(\mathrm{II})$ complex, $\left[\mathrm{Ru}(\mathrm{bpy})_{2}(\mathrm{PVP})(\mathrm{py})\right] \mathrm{Cl}_{2}$. 
The precipitate was collected and dried in vacuo.

\section{Absorption Measurement}

Electronic absorption spectra were recorded on a Hitachi EPS-3T Model spectrophotometer.

\section{Luminescence Measurement}

Emission spectra were recorded on an Union Giken Model FS-501 fluorescence spectrophotometer equipped with a $150 \mathrm{~W}$ xenon lamp. The $\mathrm{Ru}(\mathrm{II})$ complex solutions were excited at near the absorbance maxima of the complexes. Emission spectra were taken in a $2 \mathrm{~mm}$ radius round cells at $77 \mathrm{~K}$, and in $1 \mathrm{~cm}$ square cells at room temperature. The lifetimes of the excited states of the $\mathrm{Ru}(\mathrm{II})$ complexes were determined by analyzing the decay curves measured by the single photon counting method (half-width of the light pulse being $c a .2 \mathrm{~ns}$ ) at room temperature using an Ortec Inc. system with the Hitachi multichannel analyzer. Excitation wavelengths were $360-460 \mathrm{~nm}$, using a short pass filter. The emission (filtered with No. 3A filter to exclude light below $500 \mathrm{~nm}$ ) was detected with a photomultiplier.

The samples were bubbled with nitrogen for $30 \mathrm{~min}$ prior to use so as to remove oxygen. Triply distilled water and methanol of specially prepared reagent grade for spectroscopy were used. Concentrations of $\left[\mathrm{Ru}(\mathrm{bpy})_{2}(\mathrm{py})_{2}\right] \mathrm{Cl}_{2}$ and $\left[\mathrm{Ru}(\mathrm{bpy})_{2}{ }^{-}\right.$ $(\mathrm{PVP})(\mathrm{py})] \mathrm{Cl}_{2}$ were determined spectrophotometrically. $\left(\varepsilon_{460}\right.$ for the former $=6.8 \times 10^{3} \mathrm{M}^{-1} \mathrm{~cm}^{-1}$, $\varepsilon_{472}$ for the latter $=6.1 \times 10^{3} \mathrm{M}^{-1} \mathrm{~cm}^{-1}$.)

Acknowledgments. We should like to express our gratitude to Professor K. Fukui for his invaluable assistance. The devoted support in making the lifetime measurements by Professors Y. Nishijima and M. Yamamoto are gratefully acknowledged. We also thank Dr. Nishimoto for his helpful comments.

\section{REFERENCES}

1. H. Siegel and G. Brauer, Helv. Chim. Acta., 51, 1246 (1969).

2. M. Hatano, T. Nozawa, S. Ikeda, and T. Yamamoto, Makromol. Chem., 141, 11 (1971).

3. R. H. Grubbus, C. G. Gibbons, L. C. Knoll, W. D. Bonds, and C. H. Brubaker, J. Am. Chem. Soc., 95, 2373 (1973).

4. E. Tsuchida, H. Karino, H. Nishide, and Y.
Kurimura, Makromol. Chem., 175, 161 (1974).

5. E. Tsuchida and K. Honda, Polym. J., 7, 498 (1975).

6. T. Shimidzu, "Cooperative Actions in the Nucleophile-Containing Polymers,” (Adv. Polym. Sci.), 24, 56 (1977), Spring-Verlag.

7. E. Tsuchida and H. Nishide, "Molecular Properties," (Adv. Polym. Sci.), 24, 1 (1977), Springer-Verlag.

8. T. Shimidzu, H. Chiba, K. Yamazaki, and T. Minato, Macromolecules, 9, 641 (1976).

9. T. Shimidzu, J. Minamizono, Y. Akai, and H. Chiba, J. Chem. Res., (S) 348, (M) 4019 (1979).

10. T. Nozawa, M. Hatano, and S. Kambara, Makromol. Chem., 112, 73 (1968).

11. H. Bruner and J. C. Bailer, Inorg. Chem., 12, 1645 (1973).

12. E. Tsuchida, K. Honda, and H. Sato, Biopolymers, 13, 2147 (1974).

13. O. Leal, D. L. Anderson, R. G. Bowman, F. Basolo, and R. L. Burwell, Jr., J. Am. Chem. Soc., 97, 5125 (1975).

14. H. R. Allock, P. P. Greigger, J. E. Gardner, and J. L. Schmutz, J. Am. Chem. Soc., 101, 606 (1979).

15. G. Sprintschnik, H. W. Sprinschnik, P. P. Kirsch, and D. G. Whitten, J. Am. Chem. Soc., 98, 2337 (1976).

16. C. R. Bock, T. J. Meyer, and D. G. Whitten, J. Am. Chem. Soc., 96, 4710 (1974).

17. D. Maisel and H. S. Matheson, j. Am. Chem. Soc., 99, 6577 (1977).

18. J. M. Clear, J. M. Kelly, D. C. Pepper, and J. G. Vos, Inorg. Chim. Acta, 33, L139 (1979); M. Kaneko, S. Nemoto, and A. Yamada, Inorg. Chim. Acta, 44, L289 (1980); ibid., 45, L73 (1980).

19. D. Maisel, H. S. Matheson, and J. Rabani, J. Am. Chem. Soc., 100, 117 (1978).

20. B. Bosnich and F. D. Dewer, Aust. J. Chem., 19, 2229 (1966).

21. G. M. Bryant, J. E. Fergusson, and H. K. Powell, Aust. J. Chem., 24, 257 (1971).

22. T. J. Meyer, J. Am. Chem. Soc., 95, 3158 (1973).

23. C. F. Liu, N. C. Liu, and J. C. Bailar, Inorg. Chem., 3, 1197 (1964).

24. F. E. Lytle and D. H. Hercules, J. Am. Chem. Soc., 91, 253 (1969).

25. R. W. Callaham, G. M. Brown, and T. J. Meyer, Inorg. Chem., 14, 1443 (1975).

26. P. C. Ford, D. F. P. Rudd, R. G. Gaunder, and H. Taube, J. Am. Chem. Soc., 90, 1187 (1968).

27. A. M. Zwickel and C. Creutz, Inorg. Chem., 10, 2359 (1971).

28. N. E. Tokel-Takvoryan, R. E. Hemingway, and A. J. Bard, J. Am. Chem. Soc., 95, 6582 (1973).

29. F. Basolo and R. G. Pearson, "Mechanism of Inorganic Reactions," 2nd ed, Wiley, New York, N.Y., 1967.

30. G. A. Crosby, W. R. Perkins, and D. M. Klassen, J. Chem. Phys., 43, 1498 (1965). 


\section{Ruthenium(II)-Poly(4-vinylpyridine) Complexes}

31. D. M. Klassen and G. A. Crosby, J. Chem. Phys., 48, 1853 (1968).

32. J. M. Demas and G. A. Crosby, J. Mol. Spectroscopy, 26, 172 (1968).

33. J. N. Demas and A. W. Adamson, J. Am. Chem. Soc., 93, 1800 (1971).

34. F. Bolletta, M. Maestri, and L. Moggi, J. Phys.
Chem., 77, 861 (1973).

35. J. V. Houten and R. J. Watts, J. Am. Chem. Soc., 98, 4853 (1976).

36. G. D. Hager, R. J. Watts, and G. A. Crosby, J. Am. Chem. Soc., 97, 7037 (1975).

37. K. W. Hipps and G. A. Crosby, J. Am. Chem. Soc., 97, 7041 (1975). 